\title{
Increasing the natural resistance and survival of minks in case of unfavorable course of Aleutian disease
}

P.A.Rostrosa ${ }^{1}, P h D$ in Veterinary sciences, researcher (rostrosa @ inbox.ru),

A.V. Sanin', Grand PhD in Biological sciences, professor, head of the cellular immunity lab (saninalex@inbox.ru),

A.N. Narovlyansky², Grand PhD in Biological sciences, professor (narovl@yandex.ru),

A.V. Pronin ${ }^{2}$, Grand PhD in Biological sciences, professor, deputy director for science (proninalexander@yandex.ru),

T.N. Kozhevnikova², PhD in Medical sciences, researcher (tatiana140663@gmail.com).

${ }^{1}$ Saltykovsky Animal Breeding Farm JSC (2, Kuchinskoe av., Balashiha, Moscow Region, RF, 143900).

${ }^{2}$ N.F. Gamaleya Federal Research Center for Epidemiology and Microbiology of the Ministry of Health of the Russian Federation (18, Gamalei Street, Moscow, RF, 123098).

Aleutian mink disease (AMD) caused by parvovirus is a real curse of the industrial mink breeding worldwide. Most minks infected with the AMD virus die, so the symptomatic treatment is aimed to extend the life of diseased minks until the fur maturation. This review contains an analysis of data obtained from the use of Gamavit (GM) and Phosprenyl $(P P)$, which are widely used in practical veterinary medicine, including in fur animals, and have therapeutic efficacy for treating other parvovirus infections of carnivores.

Both drugs were administered to minks by mixing with feed at the rate of $0.1 \mathrm{ml}$ per $\mathrm{kg}$ of body weight for GM and 0.05 ml per $\mathrm{kg}$ of body weight for PP.

In efficiency studies of the drugs on healthy animals, it was shown that they had a positive effect on the resistance of animals to adverse impacts (infections, feeding disorders, weaning). GM was most effective for increasing the fertility and number of kits per female, as well as for reducing the alimentary anemia, while PP was effective for increasing the survival rate of kits and contributed to their growth. Both drugs stimulated phagocytosis, increased SBA and SLA.

The combined use of PP and GM increased the survival rate of young animals by $7.3 \%$ and the number of kits per female by 0.45 animals, as well as increased the number of defect-free skins by $7 \%$. In addition, it eliminated anemia and increased the level of hemoglobin and erythrocytes in minks affected with AMD, although they did not reach the lower limit of the norm. Moreover, the use of PP and GM increased the number of kits per female by 0.7 animals vs. control, while the mortality rate of young animals reduced by $9.8 \%$.

Thus, the combined use of GM and PP in minks can increase the main natural resistance indicators (SBA, SLA levels, phagocytosis indicators, the absorption ability of peripheral blood granulocytes, the activity of natural killer cells) and significantly reduce anemia. Furthermore, the combined use of the drugs can increase the survival rate of young animals, the number of kits per female, reduce the live weight decrease in kits and increase the number of defect-free skins.

Keywords: mink, Aleutian disease, parvoviruses, Phosprenyl, Gamavit, anemia.

\section{Повышение естественной резистентности и выживаемости норок при неблагополучии по алеутской болезни}

П.А. Ростроса', кандидат ветеринарных наук, научный сотрудник

A.B.Санин ${ }^{2}$, доктор биологических наук, профрессор, зав. лаб. клеточного иммунитета (saninalex@inbox.ru),

А.Н. Наровлянский², доктор биологических наук, профессор, зав. лаб. цитокинов,

А.В. Пронин ${ }^{2}$, доктор биологических наук, професссор, зам. директора по научной работе,

T.н. Кожевникова², кандидат медицинских наук, научный сотрудник лаб. клеточного иммунитета (tatiana140663@gmail.com).

${ }_{1}^{1}$ АО «Племенной зверосовхоз Салтыковский» (143900, МО, Балашиха, Кучинское шоссе, вл. 2).

2 ФГБУ «НИЦЭМ им.Н.Ф.Гамалеи» Минздрава России (123098, Москва, ул. Гамалеи, 18).

Алеутская болезнь норок (АБН), возбудителем которой служит парвовирус, является настоящим бичом gля промыиленного норково gства во всем мире. Больиинство инфицированных вирусом АБН норок погибают, поэтому цель симптоматического лечения состоит в том, чтобь про ллить жизнь больным норкам gо созревания волосяного покрова. В настояием обзоре проанализированы gанныле об использовании при АБН Гамавита (ГМ) и Фоспренила (ФП) - препаратов, иироко применяемых в практической ветеринарии, в том числе у пуиных животных, и облаяаюиих терапевтической эффективностью при яругих парвовирусных инфекциях плотоя нных. Оба препарата давали норкам, размешивая их с кормом из расчета 0,1 мл/кг массь1 тела gля ГМ, и 0,05 мл/кг массьг тела яля ФП.

При испьтании эффективности препаратов на з ооровом поголовье было показано, что они положительно влияют на устойчивость зверей к неблагоприятным возяействиям (инфекции, наруиения кормления, отсаяка). Гм был наиболее эффективен яля повышения оплодотворяемости и выхоgа щенков, а также gля уменьиения 
белопухости, а ФП - -ля повышения сохранности и активизации роста иенков. Оба препарата стимулировали фагоцитоз, повьииали БАСК и ЛАСК.

Сочетанное применение ФП и ГМ позволило повысить сохранность молояняка на 7,3 \%, увеличить выхо иенков на 0,45 щенка на самку и получить на 7 \% больше шкурок без gефектов. Также у больных АБН норок уgалось скорректировать анемию и повысить уровень гемоглобина и эритроцитов, хотя они не gостигли нижней границь нормы1. Кроме того, выход щенков от больных самок при использовании ФП и Гм был на 0,7 щ,енка вылие, чем в контроле, тогgа как отход молояняка снизился на 9,8 \%.

Таким образом, сочетанное применение ГМ и ФП норкам при АБН позволяет повысить основные показатели естественной резистентности организма (уровни БАСК, ЛАСК, показатели фагоцитоза, поглотительной способности гранулоцитов периферической крови, активности естественных киллерных клеток) и в значительной степени устранить анемию. Кроме того, сочетанное применение препаратов позволяет повысить сохранность молодняка, увеличить выхоg щенков на самку, уменьиить снижение живой массы щенков и получить больие икурок без дефектов.

Ключевые слова: норки, алеутская болезнь, парвовирусы, фоспренил, гамавит, анемия.

\begin{abstract}
Abbreviations (сокращения): AMD (АБН) - Aleutian mink disease (Алеутская болезнь норок), GM (ГМ) Gamavit (Гамавит), NK cells (EKK) - natural killer cells (естественные киллерные клетки), SLA (ЛАCK) — serum lysozyme activity (лизоцимная активность сыворотки крови), PР (ФП) - Phosprenyl (Фоспренил), SBA (БАСК) - serum bactericidal activity (бактерицидная активность сыворотки крови).
\end{abstract}

Aleutian mink disease, or viral plasmacytosis, is literally a real curse of the industrial mink breeding worldwide [45]. The disease can become epizootic with the death of up to $90 \%$ of diseased minks [43] and causes enormous economic damage manifested by a number of indicators: reduction of the total number of animals on the farm, decreased fertility of females, a mass death of mink kits, worsening of the fur quality, etc. [40, 42].

\section{Causative agent, pathogenesis, clinical signs of AMD}

The causative agent of AMD is a small DNA-containing parvovirus of the genus Amdoparvovirus, the family Parvoviridae [2]. The key virus reproduction protein is the NS1 nuclear protein, which possesses ATPase and helicase activity and contains sites through which its caspases the main mediators of apoptosis - are recognized and cleaved [13]. In addition, there are two capsid proteins, VP1 and VP2, which are the main targets for the immune response [39]. There is no clear understanding of the mechanism how the AMD virus penetrates into cells [47].

The pathogenesis of AMD is similar in some respects to some mechanisms of the development of equine infectious anemia, hemolytic anemia, murine lymphocytic choriomeningitis and African swine fever, which are characterized by hypergammaglobulinemia. Two stages are distinguished in the pathogenesis of the disease: infectious and autoimmune.

The first stage proceeds in the same way as with most viral infections - it begins after the invasion and reproduction of the virus that stimulates proliferation of plasma cells that infiltrate many organs: lymph nodes, bone marrow, spleen, liver, kidneys, etc. [2]. Then, hypergammaglobulinemia develops with gamma globulins making up to $50 \%$ of all serum proteins [38]. Interacting with the virus, antibodies form immune complexes, in which the virus preserves it infectious activity. Thus, antiviral antibodies exacerbate the development of AMD - a phenomenon of antibody-dependent enhancement of the infection can be observed. The inability of specific antibodies to neutralize the invading virus causes its lifelong persistence in the body. During the phagocytosis of immune complexes, macrophages release the virus, contributing to its subsequent multiplication in phagocytic cells. As a result, the immune response only contributes to the virus reactivation and impedes the recovery.

Moreover, the second stage with the AMD development is accompanied by an autoimmune process. The formed perivascular and glomerular complexes of the virus and antibodies are deposited on small blood vessel membranes, capillaries of renal vascular glomeruli, blood vessel walls of the liver and other organs, which leads to the development of necrotic arteritis, proliferative glomerulonephritis and other pathological conditions. It is supposed that it is the formation of such immune complexes that is the main reason for unsuccessful attempts of vaccination against AMD [37].

Clinical signs of AMD depend on the severity of the disease. Shortly before the death of the animals, they show aversion to food, depression, exhaustion, ulceration of the mucous membrane of the mouth, lips, gums, and renal failure. In addition, severe anemia develops due to the breakdown of red blood cells, decreased or inadequate erythropoiesis [44].

Most of the minks infected with the AMD virus die and those who had recovered from the disease fail to develop the immunity [40]. Formalin-inactivated vaccines against AMD contribute to only some increase in resistance of the animals. The main purpose of symptomatic treatment with vitamins, glucose, electrolyte solutions, immunomodulators, etc. is to prolong the life of sick minks before the fur maturation.

\section{Use of immunomodulators and biostimulants}

We have analyzed specific aspects of the use of immunomodulators and biostimulants in minks with AMD. In available published data, we found information on the use of drugs such as Levamisole, Thymogen, Polyoxidonium, Phosprenyl (PP) and Gamavit (GM) for this purpose. 
It was shown that in minks spontaneously infected with the AMD virus, the number of red blood cells, the levels of hemoglobin and hematocrit are significantly lower than in healthy ones [33]. Levamisole had a weak and shortlasting immunomodulating effect on the body of minks with AMD, while the administration of polyoxidonium and thymogen contributed to a certain decrease in the intensity of pathological processes and autoimmune reactions, the infiltration of immune organs by plasma and mast cells [20].

However, most studies of AMD dealt with GM and $\mathrm{PP}$ - drugs that had long been used in practical veterinary medicine, including in fur animals [1, 3, 5, 8, 33]. GM is an effective immunomodulator [10], a metabolic and hematopoietic stimulator, which is successfully used for the treatment of clinically expressed infections, including those caused by parvoviruses [30], parasitic infestations $[14,28]$, various intoxications [12, 24] and other pathological conditions and stressful physiological periods of life. Its active ingredients are sodium nucleinate and denatured placenta extract. PP (the active substance is sodium polyprenyl phosphate) is an antiviral and immunomodulating agent that is effective in many viral infections of small domestic animals $[23,26]$. It is also important that PP has proven clinical efficacy for the treatment of parvovirus infections in dogs (parvovirus enteritis) and cats (panleukopenia) $[19,26]$.

Both drugs were administered to minks by mixing with feed at the rate of $0.1 \mathrm{ml}$ per $\mathrm{kg}$ of body weight for GM and $0.05 \mathrm{ml}$ per $\mathrm{kg}$ of body weight for PP.

In efficiency studies of the drugs on healthy animals, experiments conducted on the Saltykovsky Animal Breeding Farm showed that both drugs had a positive effect on the resistance of animals to adverse impacts (infections, feeding disorders, weaning). GM was most effective for increasing the fertility and number of kits per female, as well as for reducing the alimentary anemia, while PP was effective for increasing the survival rate of kits and contributed to their growth [8]. Both drugs stimulated phagocytosis, increased SBA and SLA [9]. The incidence of staphylococcal infection in newborn kits was also prevented [21].

In another study conducted at Rechnoye CJSC in the Omsk Region, PP was administered i.m. It was found that PP increased the erythrocyte count in the peripheral blood of minks infected with the AMD virus by $13 \%(\mathrm{P}<0.05)$ and the group of sick animals treated with PP showed an increased absorption capacity of peripheral blood granulocytes and enhanced quantitative indices of the phagocytic index and phagocytic number [4]. In another study conducted by the same animal breeding farm, after administration of PP to minks infected with the AMD virus, the number of erythrocytes increased by $14.9 \%$ and the level of hemoglobin grew by $7.5 \%(\mathrm{P}<0.001$ and $\mathrm{P}<0.05$, respectively) [35].

Based on the results, a scheme was developed for the combined use of these drugs in case of unfavorable course of AMD. The purpose of this experiment was to maintain the level of natural resistance of animals spontaneously infected with AMD, to prevent the expected decrease in the number of kits per female, their death and to reduce a live weight decrease. Like in previous experiments, both drugs were given together with food in the same doses.

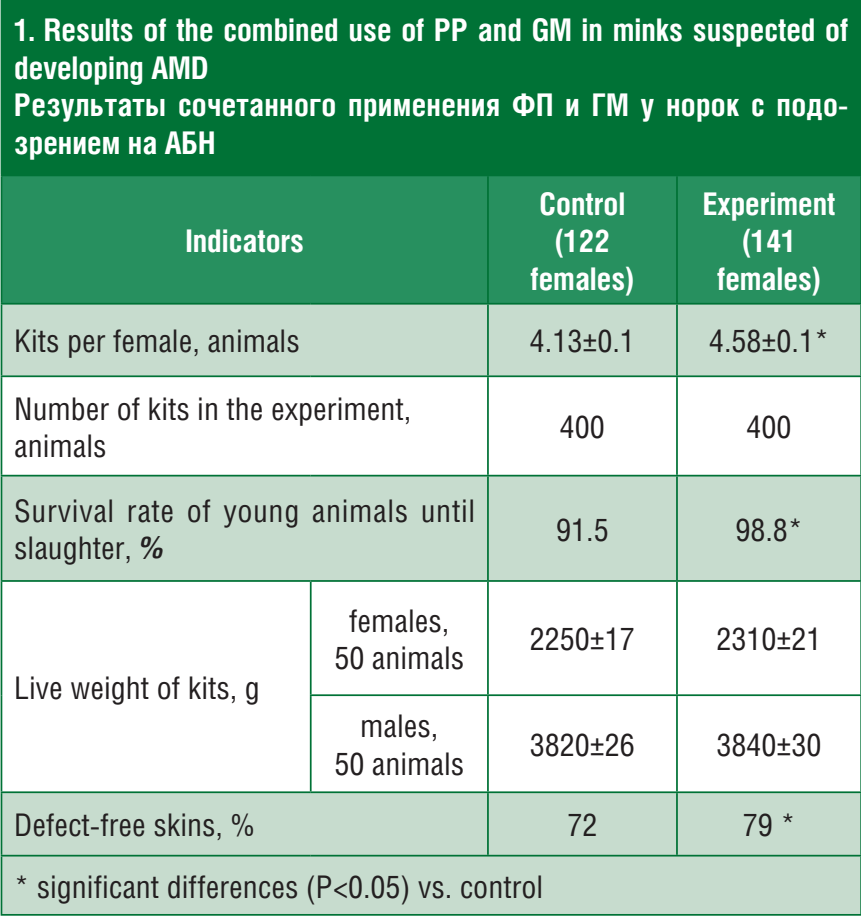

As can be seen from Table 1, the use of PP and GM allowed to increase the survival rate of young animals by $7.3 \%$ and the number of kits per female by 0.45 animals. In addition, in the experimental group, the live weight of kits increased and the number of defect-free skins was more by $7 \%[22]$.

The following series of experiments studied the effect of the combined use of GM and PP on indicators of the erythroid lineage of hematopoiesis and natural resistance. When comparing the above scheme of the combined use of GM and PP (scheme 1) with a modified scheme, in which $\mathrm{PP}$ was additionally given with feed for the second time, 3 days before blood collection (scheme 2), the following results were obtained (Table 2 ).

\begin{tabular}{|c|c|c|c|c|}
\hline Group & $\begin{array}{l}\text { Hemo- } \\
\text { globin, } \\
\text { g/l }\end{array}$ & $\begin{array}{l}\text { Erythro- } \\
\text { cytes, } \\
\text { million }\end{array}$ & SBA, \% & $S L A, \mu \mathrm{g} / \mathrm{ml}$ \\
\hline Control & $12.7 \pm 0.6$ & $4.8 \pm 0.1$ & $21.8 \pm 0.1$ & $56.7 \pm 0.9$ \\
\hline $\begin{array}{l}\text { Experiment, } \\
\text { scheme } 1 \text { (stan- } \\
\text { dard scheme of } \\
\text { PP + GM) }\end{array}$ & $13.9 \pm 0.6$ & $5.4 \pm 0.2$ & $38.6 \pm 0.3$ & $96.7 \pm 2.1$ \\
\hline $\begin{array}{l}\text { Experiment, } \\
\text { scheme } 2 \text { PP + } \\
\text { GM (+PP } 3 \text { days } \\
\text { before blood col- } \\
\text { lection) }\end{array}$ & $15.7 \pm 0.5^{\star}$ & $6.9 \pm 0.1^{* *}$ & $44.9 \pm 0.2^{* *}$ & $158.3 \pm 1.2^{\text {** }}$ \\
\hline $\begin{array}{l}\text { Physiological } \\
\text { norm }\end{array}$ & $18.1 \pm 1.2$ & $8.7 \pm 1.4$ & - & - \\
\hline
\end{tabular}


As can be seen from the data obtained, the hemoglobin level and the number of erythrocytes in control minks were lower, which is typical for anemia in AMD. In the experimental groups, the level of hemoglobin and erythrocytes significantly increased, but did not reach the norm. However, scheme 2 proved to be more effective. Similarly, the combined use of PP and GM in minks suspected of AMD according to scheme 1 resulted in an increase in SBA by 1.8 times, SLA by 1.7 times, while according to scheme $2-$ by 2.1 and 2.8 times, respectively [22]

In the next series of experiments conducted in the Saltykovsky Animal Breeding Farm, the efficiency of the combined use of PP and GM in infected females was assessed on 699 animals. They were included into an experimental group. In the control group, which included both seronegative minks (3781 animals) and minks suspected of AMD (2160 animals), $27 \%$ were positively reacting females at the beginning of the experiment. Seronegative females that remained after isolation of positively reacting ones served as additional controls.

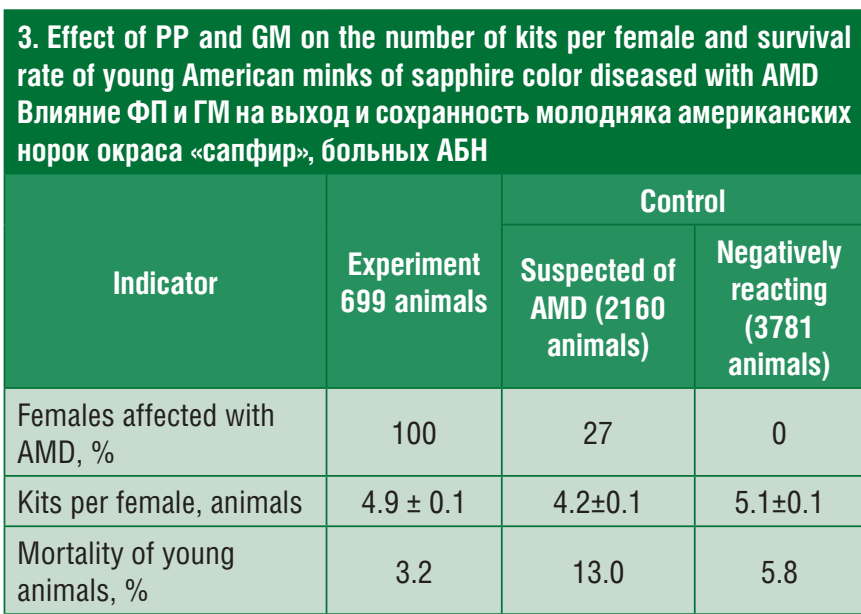

The experiments showed (Table 3 ) that the use of PP and GM increased the number of kits from diseased females by 0.7 animals vs. control (4.9 and 4.2, respectively, $\mathrm{P}<0.001)$. Moreover, the number of kits per female in the experimental group did not significantly

\section{ФОСПРЕНИЈ "ГАМАВИТ}
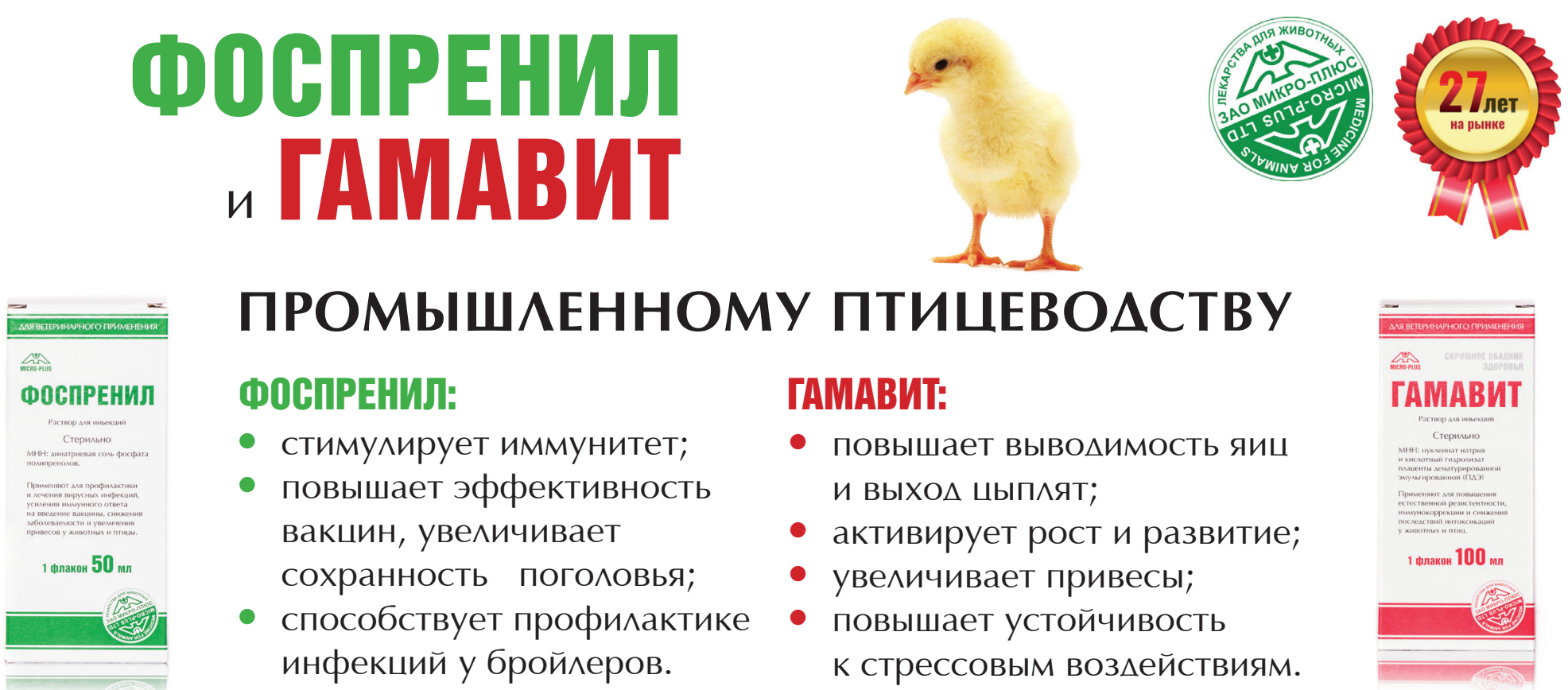

ПРОМЫШАЕННОМУ ПТИЦЕВОАСТВУ

\section{ГАМАВИТ:}

- повышает выводимость яиц и ВыхОА Шып^ят;

- активирует рост и развитие;

- увеличивает привесы;

- повышает устойчивость к стрессовым воздействиям.

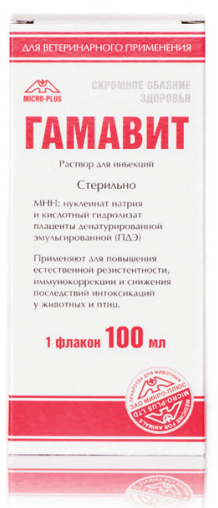

\section{Применение Фоспренима и Гамавита}

снижает затраты корма на ециницу процукции

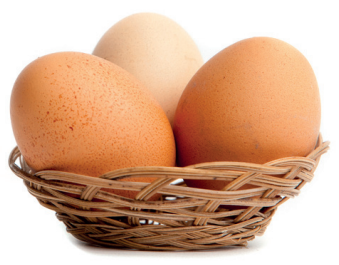

поцробнее на сайте fosprenil.ru: 
differ from negatively reacting control animals (4.9 and 5.1 , respectively; $\mathrm{P}>0.05)$. The mortality rate of young animals in the experimental group was lower by $9.8 \%$ vs. control - animals suspected of AMD (3.2 and 13\%, respectively). It should be emphasized that the mortality rate of young animals was even lower than for control negatively reacting, i.e. healthy, animals.

Since there are no effective specific remedies for treating AMD, the main task of the combined symptomatic treatment regimens for this disease is to improve the condition of sick minks, to maintain the fur quality and to prolong the life of animals to the maximum extent until the fur maturation. We believe that GM and PP are most suitable for solving this problem. The use of these drugs can increase the main natural resistance indicators (SBA, SLA levels, phagocytosis indicators, the absorption ability of peripheral blood granulocytes, the activity of NK cells), significantly reduce anemia (increase the number of erythrocytes and the hemoglobin level almost to the lower limit of the norm). In addition, the combined use of GM and PP for treating AMD can increase the survival rate of young animals, the number of kits per female, reduce the live weight decrease in kits and increase the number of defect-free skins by $7 \%$.

As one of the features of the course of AMD is antibodydependent enhancement of the disease, it is important to note that PP has proven therapeutic efficacy for treating flavivirus infections $[16,18]$, in the pathogenesis which, like in AMD, an antibody-dependent enhancement of a viral infection plays an important role [17]. In addition, hemolytic anemia, which increases with the progression of the disease, is of great importance in the pathogenesis of AMD. We cannot disregard the important role of GM in the reduction of anemia.

It has been repeatedly shown that GM eliminates anemia and restores the erythroid lineage of hematopoiesis in stressful conditions [6], congenital iron deficiency [7], blood parasitic diseases in dogs [14, 25, 27], cats [29], northern deer $[15,32]$ and other animals [26]. Moreover, GM effectively restored erythropoiesis in experimental hemolytic anemia caused by phenylhydrazine [31]. The mechanism of development of toxic anemia in the latter case is associated with a blockade in the binding of erythropoietin to receptors leading to disruption of the JAK-STAT signaling pathway and suppression of erythrocyte maturation [44]. GM has a positive effect on structures of the liver parenchyma in minks [36].

Thus, at present, GM and PP are apparently the only immunomodulatory (GM and $\mathrm{PP}$ ) and antiviral (PP) therapeutic agents with obvious therapeutic efficacy for treating AMD. It is noticeable that both drugs have also proven themselves in the treatment of other mammalian parvovirus infections - feline panleukopenia [19] and canine parvovirus enteritis $[26,30]$.

\section{Conflict of interests}

The authors state that no conflict of interests exists.

\section{References}

1. Agafonova A.D., Sanin A.V., About the use of Gamavit in rabbit breeding, Modern Farmer, 2017, No. 3, pp. 40-41. (In russ.).

2. Belousova R.V., Preobrazhenskaya E.A., Tretyakova I.V., Veterinary Virology, Moscow, KolosS, 2007, 424 p. (In russ.)
3. Belousova R.V., Vinogradova E.A., Gracheva N.S., Deeva A.V., Test of immunomodulators Phosprenyl and Gamavit on sables in industrial breeding conditions, Veterinary Medicine, 2014, No. 12, pp. 45-48. (In russ.).

4. Bespalova T.A., Sidorov G.N., Khitrova E.A., Correction of the immune status of healthy minks and minks infected with the Aleutian disease virus, Veterinary pathology, 2007, No. 3, pp. 250-253. (In russ.).

5. Vinogradova E.A., Belousova R.V. The effect of immunomodulators Phosprenyl and Gamavit on the physiological condition, immune reactivity and productivity of young sables, Veterinary medicine, 2013, No. 1, p. 40-43. (In russ.).

6. Vishnevskaya T.Ya., Abramova L.L., Comparative analysis of hematological blood parameters in stressful conditions and their immunocorrection with Gamavit. In the collection: Topical Issues of Veterinary Medicine. Proceedings of the Eleventh Siberian Veterinary Conference, 2012, pp. 59-60. (In russ.).

7. Glagoleva T.I., Zavalishina S.Yu., Medvedev I.N., Ferroglucin and Gamavit in the correction of antiaggregatory properties of blood vessels in newborn calves with iron deficiency, Successes of Modern Natural Science, 2013, No. 5, pp. 17. (In russ.).

8. Gracheva N.S., Zaytseva M.L., Deeva A.V., Rostrosa P.A., Belousova R.V., Efficiency of Phosprenyl and Gamavit in Mink Breeding. Veterinary Medicine, 2005, No. 8, pp. 13-15. (In russ.).

9. Gracheva N.S., Zaytseva M.L., Deeva A.V., Rostrosa P.A., Belousova R.V., Narutal Resistance and Productivity of Minks, Veterinary Medicine, 2005, №. 10, pp. 21. (In russ.).

10. Grigoryeva E.A.,Pronin A.V., Sanin A.V., Narovlyansky A.N., Kozhevnikova T.N., Timofeeva T.Yu., Sanina V.Yu., Stepanova T.N., Gerasimova E.V., Ivanova A.M., Effects of Gamavit on the natural killer cell activity, Veterinary Medicine of Kuban, 2016, No. 4, pp. 27-28. (In russ.).

11. Deeva A.V., Rostrosa P.A., Sokolov V.D., Belousova R.V., The use of immunomodulators Phosprenyl and Gamavit for minks in animal breeding. Guidelines, Moscow, Publishing house of the Federal State Budget Educational Institution of Higher Professional Education «K.I. Skryabin Moscow State Academy of Veterinary Medicine and Biotechnology». 2008, 16 p. (In russ.).

12. Zaitseva L.G., Bekhalo V.A., Vasiliev I.K., Godunov R.S., Kireeva I.V., Kozhevnikova T.N., Nagurskaya E.V., Narovlyansky A.N., Ozherelkov S .V., Pronin A.V., Sanin A.V., Correction of Functional activity of peritoneal macrophages of mice with Phosprenyl and Gamavit using high doses of alphatoxin of Staphylococcus aureus, Journal of Microbiology, Epidemiology and Immunology, 2005, No. 6, pp. 51-57. (In russ.).

13. Kashtanov S.N., Salnikova L.E. Aleutian mink disease: epidemiological and genetic aspects, Successes of Modern Biology, 2017, Vol. 137, No. 5, pp. 468-478. (In russ.)

14. Leonard R.A., Effect of Gamavit, Phosprenyl and Maxidin on some biochemical blood parameters in dogs suffering from piroplasmosis, Veterinary clinic, 2006, No. 3, pp. 2-5. (In russ.)

15. Liberman E.L., Georgiu Kh., Belimenko V.V., Experience of using Gamavit in the treatment of blood parasitic diseases of reindeer, Russian Veterinary Journal. Productive animals, 2014, №. 4, pp. 31-33. (In russ.).

16. Ozherelkov S.V., Timofeev A.V., Novikova G.P., Deeva A.V., Narovlyansky A.N., Sanin A.V., Pronin A.V., Protective effect of phosprenyl, a new antiviral drug, in experimental tick-borne encephalitis, Virusology Issues, 2000, Vol. 45, No.1, pp. 33-37. (In russ.).

17. Ozherelkov S.V., Kalinina E.S., Kozhevnikova T.N., Sanin A.V., Timofeeva T.Yu. Timofeev A.V., Stevenson D.R., Experimental study of the phenomenon of antibody-dependent enhancement of infectivity of the tick-borne encephalitis virus in vitro, JMEI, 2008, No. 6, pp. 39-43.

18. Ozherelkov S.V., Sanin A.V., Narovlyansky A.N., Pronin A.V., Kozhevnikova T.N., Antiviral effect of Phosprenyl and Gamapren on flaviviruses, Veterinary and Feeding, 2017, No. 3, pp. 78-79. (In russ.).

19. Pereslegina I.O., Dubrovina T.S., Klintsova T.Yu., Agafonova A.D., Zotova S.N. Comparison of two treatment regimens for panleukopenia in cats, Russian Veterinary Journal. Small domestic and wild animals, 2017, №. 5, pp. 24-28. (In russ.).

20. Ponomarenko D.G., The effect of immunomodulators on morphological and functional indicators of immune system organs of minks with Aleutian disease, Extended abstract of candidate's thesis in biological sciences, Stavropol, 2007, 24 p. (In russ.)

21. Rostrosa P.A., Zaitseva M.L., Deeva A.V., Belousova R.V., Experience of using Phosprenyl and Gamavit in mink breeding. In the collection: Medicines and animal feed. Proceedings of the Conference, Moscow, 2006, pp. 88-91. (In russ.).

22. Rostrosa P.A., Influence of immunomodulators on the immune reactivity of the organism of minks and their productivity. Extended abstract of candidate's thesis in veterinary sciences, Defense on 18.12.2008, Moscow, Company Sputnik LLC, 2008, 21 p. (In russ.). 
23. Rudneva S.Yu., Narovlyansky A.N., Pronin A.V., Stepanova T.N., Sanin A.V., Treatment of oral papillomatosis in a dog with Phosprenyl, Russian Veterinary Journal. Small domestic and wild animals, 2016, No. 3, pp. 9-11. (In russ.).

24. Salichev A.V., Ozherelkov S.V., Izmestieva A.V., Videnina A.A., Sanin A.V., Randomized, controlled, double-blind study of the antitoxic effects of Gamavit and Gamavit forte in vivo using Imidocarb dipropionate, Veterinary Medicine of Kuban, 2011, No. 6, pp. 22-25. (In russ.)

25. Samoylova E.S., Derkho M.A., From the experience of using antioxidants in a comprehensive treatment regimen for babesiosis in dogs, Veterinary Doctor 2009, No. 1, pp. 13-16. (In russ.)

26. Sanin A.V., Use of immunomodulators in viral diseases of small domestic animals. Russian Veterinary Journal. Small domestic and wild animals, 2005, No. 1, pp. 38-42. (In russ.).

27. Sanin A.V., Gamavit is an effective remedy for extracorpuscular anemia, Veterinary Clinic, 2009, No. 4, pp. 16-19. (In russ.).

28. Sanin A.V., Sosnovskaya O.Yu., Sanina V.Yu., Kozhevnikova T.N., Vasiliev I.K., Narovlyansky A.N., Pronin A.V., Specific aspects of the use of immunomodulators in parasitic invasions, Veterinary Medicine of Kuban, 2010, No. 2, pp. 15-18. (In russ.)

29. Sanin A.V., Narovlyansky A.N., Pronin A.V. Kozhevnikova T.N., Agafonova A.D., Annikova L.V., Annikov V.V., Gamavit increases the efficiency of therapy for hemobartonellosis (hemoplasmosis) in cats: a controlled study, Russian Veterinary Journal, 2017, No. 3, pp. 28-32. (In russ.).

30. Sanin A.V., Pronin A.V., Narovlyansky A.N., Timofeeva T.Yu., Sanina V.Yu., Gerasimova E.V., Klyagina M.S., Zubashev I.K., Stepanova T.N., Vyshivkina N.V., Chermoshentseva G.V., Annikov V.V., Therapeutic efficacy of Gamavit in the treatment of dogs with parvovirus enteritis: a controlled study, Russian Veterinary Journal. Small domestic and wild animals, 2016, No. 5, pp. 16-20. (In russ.)

31. Sanin A.V., Narovlyansky A.N., Pronin A.V., Kozhevnikova T.N., Sosnovskaya O.Yu., Zhavnis S.E., Ozherelkov S.V., Klimova D.A., Gamavit for the correction of toxic hemolytic anemia and stimulation of erythropoiesis, Veterinary Medicine, 2018, No. 10, pp. 54-59. (In russ.).

32. Siben A.N., Liberman E.L., Silivanova E.A., Effect of immunomodulators and anthelmintics on the blood condition of reindeer, Veterinary Newsletter, 2015, No. 3(74), pp. 64-69. (In russ.)

33. Slobodyanik V.I., Zhukov S.P., Kustov M.A., Efficiency of Phosprenyl in the production of rabbit meat, Rabbit and fur animal breeding, 2005, Vol. 5, pp. 8-19. (In russ.).

34. Khitrova D.A., Physiological aspects of the natural resistance and immune reactivity of healthy minks and minks spontaneously infected with the Aleutian disease virus, Extended abstract of candidate's thesis in biological sciences, Defended on 17.12 2003, Omsk, Publishing House of the Omsk State Medical Academy, 2003, 14 p. (In russ.)
35. Khitrova E.A., Effect of biologically active substances on the immune status of minks suffering from the Aleutian disease and immunodeficiency disorders, Extended abstract of candidate's thesis in biological sciences, Defended on 25.02 2009, Omsk, Publishing House of the Omsk State Medical Academy, 2009, $19 \mathrm{p}$

36. Choporova N.V., Shubina T.P., Morphological changes in the liver of a standard mink in the age aspect and after the use of Gamavit, Bulletin of the Don State Agrarian University, 2019., No. 1-1, pp. 10-16. (In russ.).

37. Aasted B., Alexandersen S., Christensen J., Vaccination with Aleutian mink disease parvovirus (AMDV) capsid proteins enhances disease, while vaccination with the major non-structural AMDV protein causes partial protection from disease, Vaccine, 1998, Vol. 16, No. 11-12, pp. 1158-1165.

38. Best S.M., Bloom M.E., Pathogenesis of Aleutian mink disease parvovirus and similarities to b19 infection, J. Vet. Med. B. Infect. Dis. Vet. Public. Health. 2005, Vol. 52, No. 7-8, pp. 331-334.

39. Bloom M.E., Best S.M., Hayes S.F., Wells R. D., Wolfinbarger J. B., McKenna R., and Agbandje-McKenna M., Identification of Aleutian mink disease parvovirus capsid sequences mediating antibody-dependent enhancement of infection, virus neutralization, and immune complex formation, J. Virol., 2001, Vol. 75, No. 22, pp. 11116-11127.

40. Canuti M., Whitney H.G., Lang A.S., Amdoparvoviruses in small mammals: expanding our understanding of parvovirus diversity, distribution, and pathology, Front. Microbiol., 2015, Vol. 6, pp. 1119.

41. Canuti M., O'Leary K.E., Hunter B.D., Spearman G., Ojkic D., Whitney H.G \& Lang A.S., Driving forces behind the evolution of the Aleutian mink disease parvovirus in the context of intensive farming, Virus Evolution, 2016, Vol. 2, No. 1. view004. https://www.ncbi.nlm.nih. gov/pubmed/ 27774297

42. Jensen T.H., Chriél M., Hansen M.S., Progression of experimental chronic Aleutian mink disease virus infection, Acta Vet. Scand., 2016, Vol. 58, No. 1 pp. 35.

43. Li Y., Huang J., Jia Y., Du Y., Jiang P, Zhang R., Genetic characterization of Aleutian mink disease viruses isolated in China, Virus Genes, 2012, Vol. 45, No. 1, pp. 24-30.

44. McGuire T.C., Perryman L.E., Gorham J.R., Mechanisms of anemia in Aleutian disease viral infection of mink, Veterinary Microbiol., 1979, Vol. 4, Issue 1, pp. 17-27.

45. Nituch L.A., Bowman J., Wilson P., Schulte-Hostedde A.I., Molecular epidemiology of Aleutian disease virus in freeranging domestic, hybrid, and wild mink, Evol. Appl., 2012, Vol. 5, No. 4, pp. 330-340

46. Pandey K., Meena A.K., Jain A., Singh R.K., Molecular mechanism of phenylhydrazine induced haematotoxicity: a review, American Journal of Phytomedicine and Clinical Therapeutics, 2014, Vol. 2, No. 3, pp. 390-394.

47. Park G.S., Best S.M., Bloom M.E., Two mink parvoviruses use different cellula receptors for entry into CRFK cells, Virology, 2005, Vol. 340, No. 1, pp. 1-9.

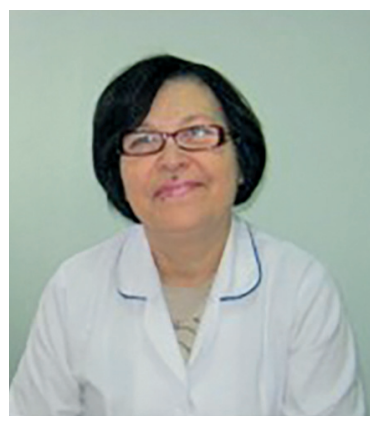

\section{Юбилей: 65 лет М.П. Михайловой}

Заслуженному ветеринарному врачу РФ, заместителю начальника ГБУ ЛО «СББЖ Ладейнопольского и Подпорожского районов» Марии Петровне Михайловой 07.10.2019 года исполнилось 65 лет.

После окончания средней школы, М.П. Михайлова поступила в Ленинградский ветеринарный институт. В 1979 г. успешно окончила его и была направлена в Одесскую область, где работала ветврачом на овцеводческом комплексе. В 1980 г. была принята на работу в качестве ветврача молочного комплекса на 1200 голов в Подпорожском районе Ленинградской области, где решала проблемы поддержания генофонда айрширской породы, внедряя практику искусственного осеменения коров.

В крупных комплексах с беспривязным содержанием животных, при их большом скоплении на ограниченных площадях нужно было тщательно проводить противоэпизоотические мероприятия по туберкулезу, бруцеллезу и лейкозу. В1997 г. Подпорожский район был оздоровлен от лейкоза. Была внедрена диспансеризация всего поголовья, что позволило своевременно выявлять больных коров и проводить лечебно-профилактические мероприятия. Существенно уменьшились заболеваемость по незаразным болезням, в том числе акушерско-гинекологической патологии, и яловость, снизилась заболеваемость по хирургическим болезням. В 90-е годы, когда не хватало квалифицированных животноводов, в Подпорожье при профтехучилище № 244 М.П. Михайлова открыла курс, где обучала будущих операторов машинного доения основам животноводства, физиологии животных и технологии доения коров.

За заслуги в области сельского хозяйства и многолетний, добросовестный труд Указом Президента Российской Федерации от 06.08.1997 года М.П. Михайловой присвоено звание «Заслуженный ветеринарный врач РФ».

Коллектив станции и друзья Марии Петровны сердечно поздравляют ее с юбилеем, желают крепкого здоровья, счастья в личной жизни и новых творческих успехов.

А.Я. Батраков, В.Н. Виденин, Е.Е. Макеева 